\title{
Thermoeconomic Analysis of Combined Production of Electricity and Second Generation Ethanol Based on the Dilute Acid Hydrolysis of Sugarcane Bagasse
}

\author{
D.N. Flório ${ }^{1}$ S. Oliveira Junior ${ }^{* 2}$ \\ Mechanical Engineering Department. Polytechnic School of the University of São Paulo, Av. Prof. Mello \\ Moraes, 2231, 05508-900, São Paulo, Brazil \\ E-mail: ${ }^{2}$ soj@usp.br
}

\begin{abstract}
In this study, a thermoeconomic assessment of an integrated ethanol production from sugarcane bagasse and traditional sugarcane juice is developed and discussed. An integrated distillery, which works with first and second generation ethanol production routes, is modeled and simulated. The thermoeconomic model assumes that the only agricultural input to the processes is the sugarcane itself (straw or other wastes recovered from the field were not considered in the analysis). The analyses are carried out for three operating scenarios: scenario I describes a traditional distillery or a first generation distillery; scenario II takes into account an integrated distillery operating with current acid hydrolysis technology; scenario III describes an improved distillery which operates with future technology for hydrolysis and pentose fermentation. Exergy analysis, production cost analysis and economic viability assessment are carried out for each scenario. As a result, it can be concluded that the global exergy efficiency decreases with the bagasse hydrolysis for scenario II. This situation is reversed when pentose fermentation is considered in scenario III. The economic viability assessment shows that hydrolysis is not viable in the present Brazilian economic scenario because it causes a drop of $4.0 \%$ in the internal rate of return (IRR) for scenario II and $2.3 \%$ for scenario III, when compared to scenario I.
\end{abstract}

Keywords: Exergy; acid hydrolys; biofuel; cogeneration; second generation ethanol.

\section{Introduction}

Brazil is the second largest ethanol producer in the world, the largest exporter, the international leader in terms of biofuels and the first economy that has reached a sustainable use of it. Brazil and the United States lead the ethanol production worldwide. In 2006, they accounted for $89 \%$ of the global output and nearly $90 \%$ of ethanol as fuel [1].

In 2011, Brazil produced nearly 21 billion liters of ethanol [2]. Brazilian ethanol industry has 90 years of history and sugarcane is the main agricultural raw material. Going further, regulation enacted by the Federal Government states that all gasoline sold in the country must be blended with $25 \%$ ethanol, and since July 2009, more than 8 million vehicles can run on $100 \%$ ethanol or any combination of ethanol and gasoline. These cars are popularly called "flex".

Currently, ethanol production in Brazil is based on first generation technologies, i.e., it uses only sucrose, which represents one third of energy stored in sugarcane [3]. The bagasse is used primarily as an energy source for steam generation in boilers. However, it is possible to transform cellulose present inside the bagasse to sucrose through a hydrolysis reaction, which is known as second generation technology.

Second generation biofuels are produced from lignocellulosic materials such as cereal straw, forest residues, bagasse, and purpose-grown energy crops such as vegetative grasses and short rotation forests. This technology could avoid many of the concerns that first generation biofuels face and potentially offers greater cost reduction in the long term.

In the sugarcane industry, another advantage for the use of lignocellulosic material as feedstock for bioethanol production is clear: since it is already available in plant site (for bagasse), or close to it (trash), second generation bioethanol production may share part of the infrastructure where first generation ethanol production takes place, for instance, concentration, fermentation, distillation, storage and cogeneration facilities [4].

An important factor in the current Brazilian ethanol program is the production of large amounts of electricity by burning the excess bagasse. In the early days of the program, bagasse was burnt inefficiently to produce heat and work required for the industrial process (crushing, fermentation and distillation), and a good portion of it was then wasted. Nowadays high-pressure boilers can operate around 100 bar (in contrast with 20 bar in the past). As a result, a portion of the energy can be supplied to the local electricity grid.

\section{Objectives}

In this study, a thermoeconomic model that evaluates the integrated ethanol production from sugarcane bagasse and traditional sugarcane juice is developed. The model is applied to a hybrid distillery, which works with both first and second generation juices. The model assumes that the only agricultural feedstock to processes is the sugarcane itself, i.e. straw or other waste recovered from the field were not considered in the analysis and the surplus 
electricity will be sold to the public grid. The analysis will be carried out considering three complementary approaches; (i) The exergy analysis evaluates exergy use of the inputs until the final products and then identifies the main sources of irreversibilities in a given production route; (ii) The cost analysis that aims to obtain the production cost of ethanol and electricity; (iii) The economic viability assessment intends to assess the viability in terms of return on investment.

Three different scenarios were defined. Scenario I depicts a traditional distillery or a first generation distillery, scenario II represents a hybrid distillery that operates with current technology for hydrolysis (base case), and scenario III takes into account an improved distillery which operates with future technology for hydrolysis and pentose fermentation. Exergy analysis, production cost analysis and economic viability assessment will be carried out for each scenario.

\section{Methods}

\subsection{Exergy and Thermoeconomic Analysis}

Assuming all processes in steady state and neglecting variations in kinetic and potential energies, the mass, energy, exergy and cost balances for each control volume and every production route, take respectively, the form of Eqs. (1) - (4):

$$
\begin{aligned}
& \sum_{i=1}^{n} \dot{m}_{\text {in }}-\sum_{i=1}^{n} \dot{m}_{\text {out }}=0 \\
& \sum_{i=1}^{n} \dot{Q}_{i}-\dot{W}+\sum_{i=1}^{n} \dot{m}_{\text {in }} h_{\text {in }}-\sum_{i=1}^{n} \dot{m}_{\text {out }} h_{\text {out }}=0 \\
& \sum_{i=1}^{n} \dot{Q}_{i}\left(1-\frac{T_{0}}{T_{i}}\right)-\dot{W}+\sum_{i=1}^{n} \dot{m}_{\text {in }} b_{\text {in }}-\sum_{i=1}^{n} \dot{m}_{\text {out }} b_{\text {out }}=\dot{I} \\
& \sum_{i=1}^{n}(\dot{m} b c)_{\text {in }}+c_{W} \dot{W}+\dot{Z}=\sum_{i=1}^{n}(\dot{m} b c)_{\text {out }}+c_{Q} \dot{Q}
\end{aligned}
$$

Where $\dot{m}_{\text {in (out) }}$ represents mass flow rate entering (exiting) the control volume $(\mathrm{kg} / \mathrm{s}), \dot{Q}_{\mathrm{i}}$ heat transfer rate $(\mathrm{kW}), \dot{W}$ shaft power $(\mathrm{kW}), h$ specific enthalpy $(\mathrm{kJ} / \mathrm{kg}), b$ specific exergy $(\mathrm{kJ} / \mathrm{kg}), T_{0}$ ambient temperature $(\mathrm{K}), \dot{I}$ irreversibility rate $(\mathrm{kW}), c$ specific monetary exergy cost $(\mathrm{R} \$ / \mathrm{kJ})$ and $\dot{Z}$ the depreciation rate of equipment $(\mathrm{R} \$ / \mathrm{s})$ which is calculated by Eqs. (5) and (6):

$$
\dot{Z}=\frac{C_{e}\left(f_{a}+f_{o m f}+F C f_{o m v}\right)}{T_{o p e r} 3,600}
$$

$f_{a}=\frac{j(1+j)^{N}}{(1+j)^{N}-1}$

where $C_{e}$ is the acquisition cost of the equipment $(\mathrm{R} \$)$, $f_{\text {a }}$ capital recovery factor, $f_{\text {omf }}$ fixed cost associated with the equipment operation $(9 \%), f_{\text {omv }}$ variable cost of the equipment $(1 \%), F C$ the load factor $(0.75), \mathrm{j}$ interest rate (12\%), $T_{\text {oper }}$ expected yearly operation time (5,000 hours) and $N$ equipment lifetime (20 years). The set of equations was solved simultaneously using EES $^{\circledR}$ software [5].

\subsection{Development of the Model}

The thermodynamic model used in this study is based on performance prediction models of three plants available in the literature. The first one is a utilities plant with subcritical Rankine cycle [6], the second one is a distillery plant [7], and the third one is a hydrolysis plant [8]. Each one of them will be explored separately and the complete model to be solved in this study arises from the assembly of these three sub-models. The implementation of the model corresponds to mass, energy, exergy, and monetary exergy cost balances for each control volume, as stated before.

\subsubsection{Distillery}

Ethanol is produced by fermentation of the sugarcane juice as well as the juice obtained from the bagasse hydrolysis. Thus, the modelled distillery can be considered a hybrid one, i.e., a combination of first and second generation production routes, as shown in Fig. 1 and described in detail by [9]. The following processes were modelled thermodynamically: (i) washing, (ii) extraction,

\begin{tabular}{|c|c|}
\hline Parameter & Value \\
\hline Capacity $^{2}$ & $2500000 \mathrm{TC} /$ year $^{\mathrm{a}}$ \\
\hline Sugarcane Processed (wet basis) ${ }^{2}$ & $500 \mathrm{TC} / \mathrm{h}^{\mathrm{a}}$ \\
\hline Yearly Operation & 5000 hours/year \\
\hline Sugarcane Fiber Content (wet basis) ${ }^{2}$ & $14.0 \%$ \\
\hline Sugarcane Sucrose Content (wet basis) ${ }^{2}$ & $14.0 \%$ \\
\hline Sugarcane Moisture Content & $70.5 \%$ \\
\hline $\begin{array}{l}\text { Juice Extraction Efficiency (Fermentable sugar } \\
\text { recovery) }\end{array}$ & $97.0 \%$ \\
\hline $\begin{array}{l}\text { Sucrose Fermentation Efficiency (Sucrose mass } \\
\text { converted to alcohol) }{ }^{2}\end{array}$ & $89.0 \%$ \\
\hline Bagasse Moisture Content ${ }^{1}$ & $50.0 \%$ \\
\hline Hydrated Ethanol Purity ${ }^{2}$ & $93.7 \%$ \\
\hline Process Steam Pressure $^{2}$ & 2.5bar \\
\hline $\begin{array}{l}\text { Sugarcane Bagasse Cellulose Content (dry } \\
\text { basis) }^{1}\end{array}$ & $43.4 \%$ \\
\hline $\begin{array}{l}\text { Sugarcane Bagasse Hemicellulose Content (dry } \\
\text { basis) }{ }^{1}\end{array}$ & $25.6 \%$ \\
\hline Sugarcane Bagasse Lignin Content (dry basis) ${ }^{1}$ & $23.2 \%$ \\
\hline Sugarcane Bagasse Ash Content (dry basis) & $1.0 \%$ \\
\hline $\begin{array}{l}\text { Distillation Steam Consumption (Distillery } \\
\text { Plant) }\end{array}$ & $2.5 \mathrm{~kg} / \mathrm{kg}$ of ethanol \\
\hline $\begin{array}{l}\text { Distillation Mass Recovery Efficiency } \\
\text { (Distillery Plant) }\end{array}$ & $99 \%$ \\
\hline $\begin{array}{l}\text { a - TC - metric tons of sugarcane. } \\
1-[4] \\
2-[7] \\
3-[6]\end{array}$ & \\
\hline
\end{tabular}
(iii) juice treatment, (iv) evaporation (v) fermentation, (vi) distillation and rectification, and (vii) cooling. Table 1 shows data related to these processes.

Table 1. Distillery Parameters. 


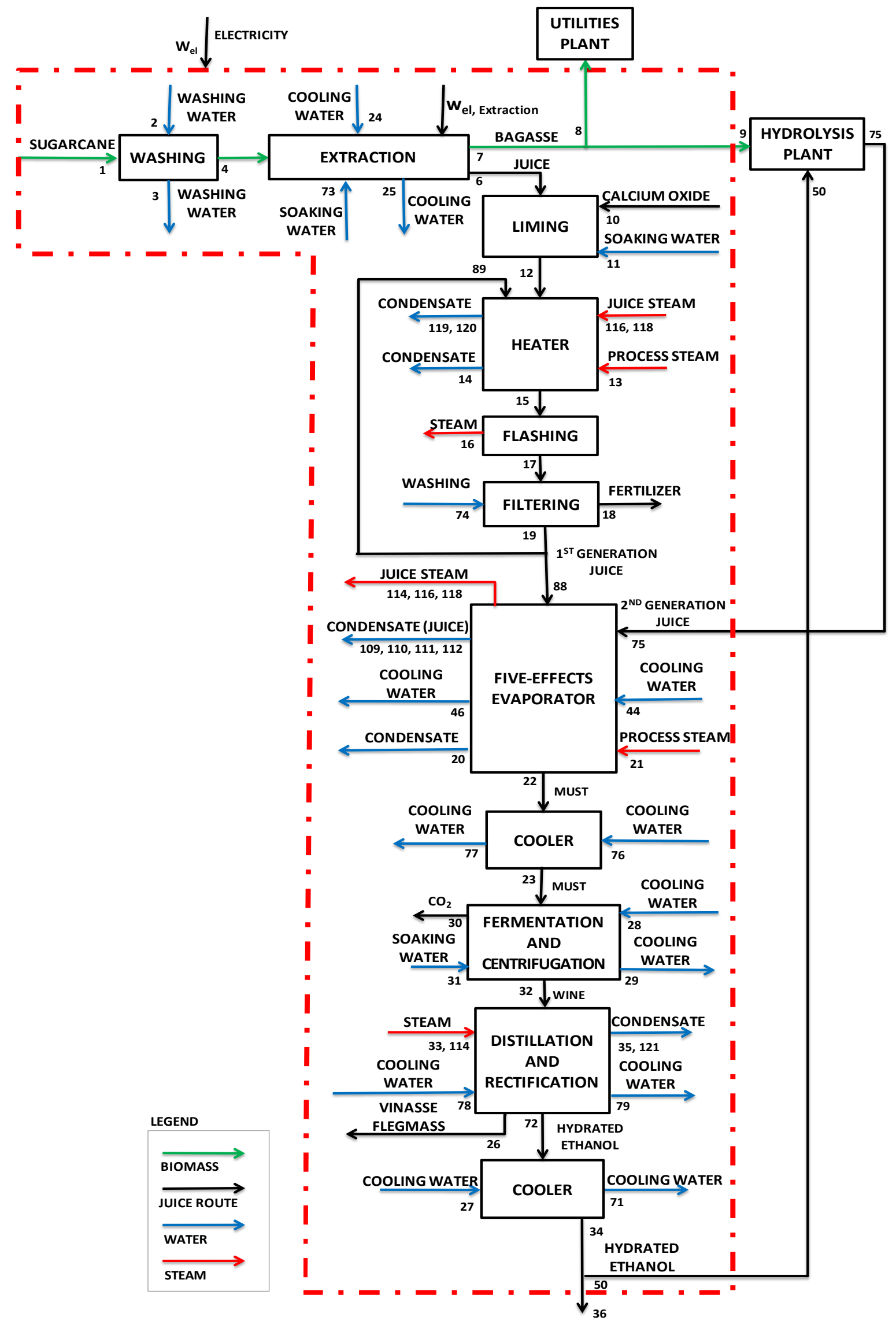

Figure 1. Distillery plant.

\subsubsection{Utilities Plant}

In Brazil, backpressure systems normally operate at 21 bar and $300^{\circ} \mathrm{C}$. Steam is expanded in single-stage turbines (turbo pumps and mills) and / or multistage (turbo) until the process pressure, around 2.5 bar [6] is reached.
By increasing steam temperature and pressure in the boiler, the surplus electricity generated can be sold to the grid in greater amounts. Furthermore, the use of extractioncondensing turbines makes it possible to generate and sell electricity in the period between harvests. 
New plants and units, seeking to improve their energy balances, opt to use boilers with pressures up to 100 bar in order to facilitate the sale of surplus electricity. The use of higher pressures is limited to 180 bar due to equipment cost and to economic and financial issues related to the sale of surplus electricity. The efficiency of these new boilers is $85-87 \%$ (based on Lower Heating Value, LHV), and it can be raised to $89-90 \%$ in case of burning dry bagasse [6].

The utilities plant modelled in this study, differently from the standard Brazilian backpressure system, operates on a Rankine cycle with a condensing-extraction turbine. The extraction is done twice: steam at 13 bar is required to provide heat to the hydrolysis plant, and steam at 2.5 bar is used for the remainder heat demands, e.g. distillation, evaporation and heating, as shown in Fig. 2. No pressure drop in the piping and heat exchangers was considered for the simulation. The main parameters used to model the utilities plant are presented in Table 2 .

Table 2. Utilities Plant Operating Parameters.

\begin{tabular}{ll}
\hline Parameter & Value \\
\hline Steam Generation Pressure & 60 bar \\
Steam Generation Temperature & $450^{\circ} \mathrm{C}$ \\
Boiler Efficiency (LHV basis) $^{1}$ & $82 \%$ \\
Turbine Isoentropic Efficiency $^{1}$ & $85 \%$ \\
Pump Isoentropic Efficiency $^{1}$ & $80 \%$ \\
Make up Water $^{1}$ & $5 \%$ \\
Electric Generator Efficiency $^{2}$ & $95 \%$ \\
\hline $1-[6]$ & \\
$2-[4]$ &
\end{tabular}

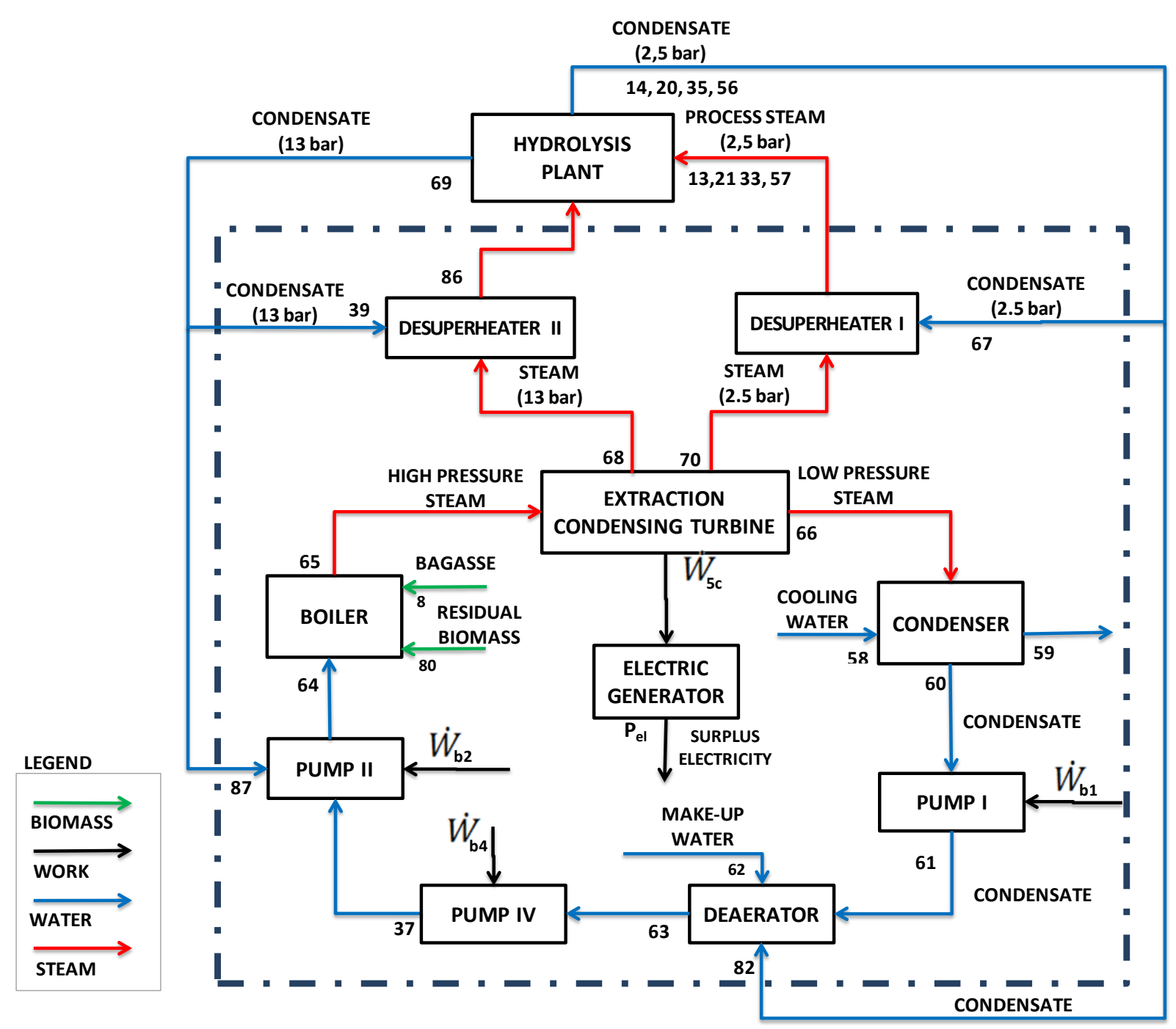

Figure 2. Utilities plant.

\subsubsection{Hydrolysis Plant}

The hydrolysis plant operates on the process DHR (Dedini Rapid Hydrolysis), which combines the organosolv pre-treatment of bagasse with the dilute acid rapid hydrolysis [10].

The pre-treatment process and the hydrolysis of cellulose and hemicellulose occurs simultaneously in a counter current reactor fed with bagasse from the top and with a mixture of ethanol $(75 \%$ weight/weight $)$ and diluted sulphuric acid $(0.25-0.5 \%$ weight/weight), under pressure of $25-28$ bar and temperature of $180-200^{\circ} \mathrm{C}$ [11]. The fluxes meet in the middle part of the reactor, where cooking takes place between the lignocellulosic biomass and the ethanol-water mixture responsible for promoting delignification and the hydrolysis reaction. The weight ratio bagasse, ethanol-water mixture, sulphuric acid at $98 \%$, is 100:600:0.1 [11]. The time that the mixture remains in the reactor varies from a few seconds to a few minutes. The residual biomass, composed primarily of lignin, is recovered and burnt in the boiler.

Upon leaving the reactor, the slightly acid solution with high sugar content is immediately cooled as a result of the expansion in the valve, which is modelled as isenthalpic, 
thereby preventing degradation of formed sugars. The cold liquor is routed to a distillation column where ethanol is recovered at the top of the column and returned to the process. The aqueous solution containing sugar is removed from the bottom of the reactor. Fig. 3 shows the hydrolysis synthesis plant.
Steam consumption in the distillation column is determined by applying the first principle of thermodynamics Eq. (2) in the distillation control volume. Due to the small amount of sulfuric acid, only ethanol, water and sucrose were taken into account to assess steam consumption. The parameters used in this control volume are detailed in Table 3.

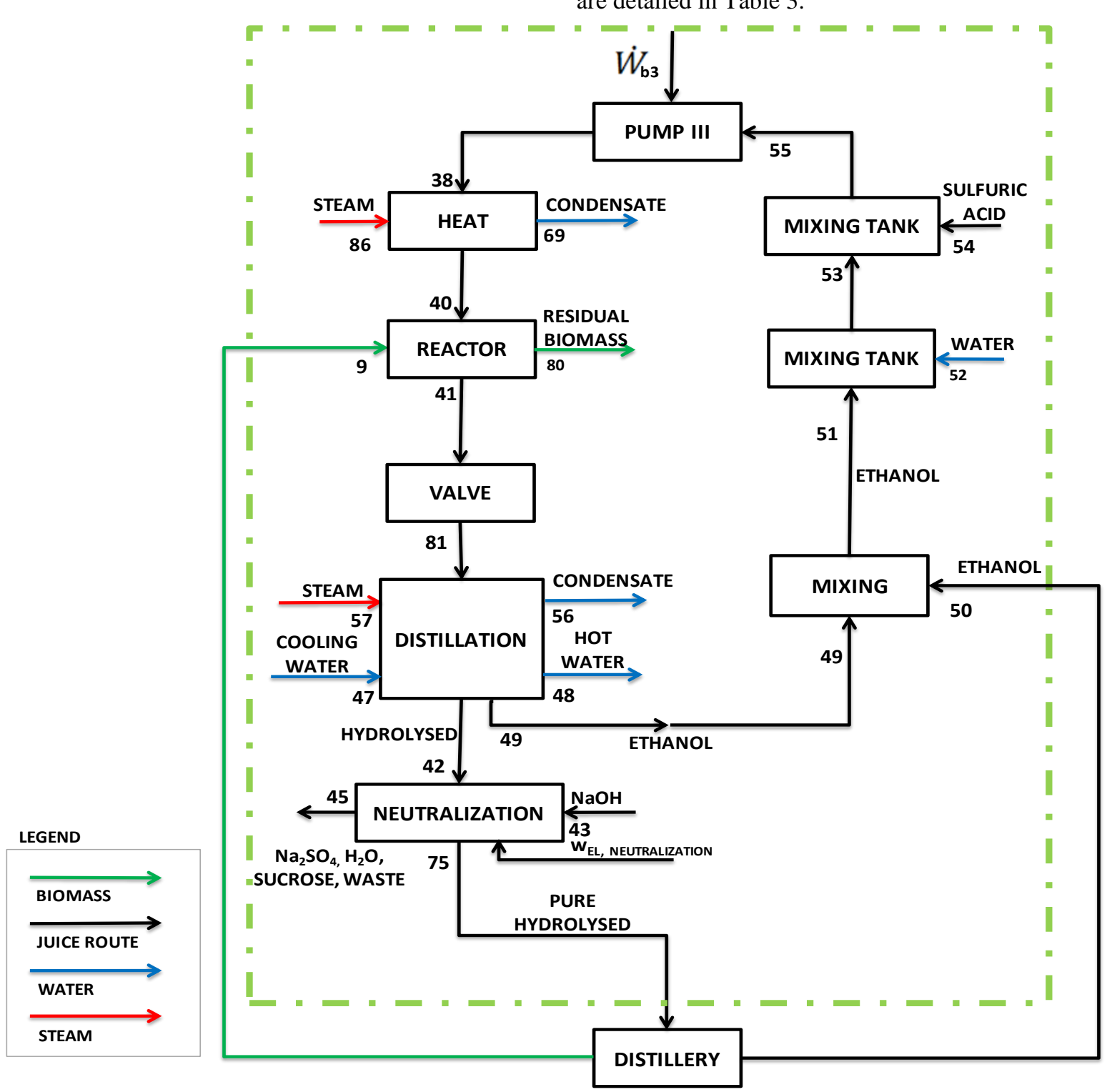

Figure 3. Hydrolysis synthesis plant.

Table 3.Hydrolysis Juice Distillation Parameters.

\begin{tabular}{lc}
\hline Parameter & Value \\
\hline Ethanol Concentration in the Reactor $(\%$ & 72.20 \\
weight/weight) & \\
Sulfuric Acid Concentration in the Reactor $(\%$ & 0.35 \\
weight/weight) & 27 \\
Pressure in the Reactor (bar) & 190.0 \\
Temperature in the Reactor $\left({ }^{\circ} \mathrm{C}\right)$ & 99.8 \\
Hydrolysed Juice Exit Temperature $\left({ }^{\circ} \mathrm{C}\right)$ & 77.8 \\
Ethanol Exit Temperature $\left({ }^{\circ} \mathrm{C}\right)$ & 93.7 \\
Ethanol Exit Concentration $(\%$ weight/weight) & 2133 \\
Ethanol Condensation Thermal Load $(\mathrm{kJ} / \mathrm{kg}$ of & \\
ethanol) & 1 \\
\hline
\end{tabular}

$1-[7]$

The plants are designed to minimize external water consumption. A cooling tower system collects the condensate of juice steam as well as the water used in cooling processes in order to reuse it by providing cool water for the processes. As a result, the external water consumption represents less than $10 \%$ of the water needed for the processes.

\section{Results and Analysis}

Three scenarios were defined in order to analyse the results. Table 4 shows the parameters of each scenario.

Because of most fermentable sugar is from the first generation plant, steam consumption in the distillery plant is slightly affected by hydrolysis yield or pentose fermentation. The simulation shows that for scenarios II and III, steam consumption in the hydrolysis plant limits to $18 \%$ the amount of bagasse that can be hydrolysed. This is a direct consequence of the steam requirement in the distillation and heating process inside the hydrolysis plant, which is approximately the same for both scenarios II and III. Table 5 presents key points process values obtained from the base case simulation. 


\subsection{Exergy Analysis - Base Case}

\section{- Distillery}

Sugarcane exergy is the main input for the distillery. It represents $87.4 \%$ of the overall input, followed by process steam, $3.3 \%$. From the perspective of exergy destruction, irreversibilities consume $16.8 \%$, followed by $12.4 \%$ in wastes. The product (ethanol) and by-product (bagasse) take $30.2 \%$ and $40.8 \%$ respectively.

The detailed study of each control volume reveals that the main source of irreversibility is the fermentation process that consumes $13.2 \%$ of the input exergy.

- Utilities Plant

Sugarcane bagasse represents $97.6 \%$ of the total exergy input for the utilities plant. From the perspective of exergy destruction, irreversibilities are responsible for $72.7 \%$. They are mainly concentrated in the combustion process, inside the boiler control volume, with $69.3 \%$.
The products carry $27.2 \%$ of the input exergy, $14.1 \%$ for process steam, $13.1 \%$ for the electricity and $2.3 \%$ for the sugarcane crushing work.

- Hydrolysis Plant

Sugarcane bagasse is the main input for the hydrolysis plant. It represents $60.7 \%$, followed by process steam with $21.5 \%$. The irreversibilities, concentrated mainly in the reactor and in the distillation process, consume $27.6 \%$ of the total input. The residual biomass composed primarily of lignin takes $33.6 \%$ and the juice composed of fermentable sugars takes $13.1 \%$.

\section{- Global Plant}

The plant composed of the distillery, utilities plant and hydrolysis plant destroys $55.1 \%$ of the input exergy. The products take $38.2 \%$ of the input exergy, being $34.2 \%$ for ethanol and $4.1 \%$ for the surplus electricity.

Table 4. Scenarios.

\begin{tabular}{|c|c|c|c|}
\hline & Scenario I & $\begin{array}{c}\text { Scenario II } \\
\text { (Base Case) }\end{array}$ & Scenario III \\
\hline Description & First Generation & $\begin{array}{c}\text { Current Hydrolysis } \\
\text { Technology }\end{array}$ & $\begin{array}{c}\text { Future Hydrolysis } \\
\text { Technology }\end{array}$ \\
\hline Pentose Fermentation & - & No & Yes \\
\hline Hydrolysis - Cellulose Conversion ${ }^{3}$ & - & $50 \%$ & $70 \%$ \\
\hline Hydrolysis - Hemicellulose Conversion ${ }^{3}$ & - & - & $70 \%$ \\
\hline Pentose Fermentation Efficiency ${ }^{1}$ & - & - & $80 \%$ \\
\hline Filters - Soluble Solids Losses ${ }^{1}$ & - & $90 \%$ & $90 \%$ \\
\hline Investment $(\mathrm{R} \$ \text { Million })^{2}$ & 317.7 & 381.2 & 381.2 \\
\hline Residual Biomass Burning & - & Yes & Yes \\
\hline Electricity Consumption (Hydrolysis Plant) ${ }^{1}$ & - & $24 \mathrm{kWh} / \mathrm{TC}$ & $24 \mathrm{kWh} / \mathrm{TC}$ \\
\hline Reaction Temperature & - & $190^{\circ} \mathrm{C}$ & $190^{\circ} \mathrm{C}$ \\
\hline Reaction Time & - & $5 \mathrm{~min}$ & $5 \mathrm{~min}$ \\
\hline Sugarcane Bagasse Hydrolysed & $0 \%$ & $15 \%$ & $15 \%$ \\
\hline Capacity (Dry Basis) & - & $100 \mathrm{t} /$ year & $100 \mathrm{t} /$ year \\
\hline
\end{tabular}

$1-[4]$

2 - Changes in equipment capacity were correlated to costs considering a coefficient of 0.6 and exchange rate of $2.00 \mathrm{R} \$ / \mathrm{US} \$$ [12]

$3-[13]$

Table 5. Key Points Process Parameters - Base Case.

\begin{tabular}{cccccc}
\hline $\begin{array}{c}\text { Key } \\
\text { Points }\end{array}$ & $\begin{array}{c}\dot{\mathrm{m}} \\
(\mathrm{kg} / \mathrm{s})\end{array}$ & $\begin{array}{c}\mathrm{P} \\
(\mathrm{kPa})\end{array}$ & $\begin{array}{c}\mathrm{T} \\
\left({ }^{\circ} \mathrm{C}\right)\end{array}$ & $\begin{array}{c}\mathrm{b} \\
(\mathrm{kJ} / \mathrm{kg})\end{array}$ & $\begin{array}{c}\mathrm{c} \\
\left(10^{-6} \mathrm{R} \$ / \mathrm{kJ}\right)\end{array}$ \\
\hline 1 & 138.9 & 101.3 & 25.0 & $5,695.0$ & 13.0 \\
6 & 143.6 & 600.0 & 35.0 & $2,931.0$ & 15.1 \\
8 & 31.4 & 101.3 & 35.0 & 9985.0 & 15.1 \\
12 & 147.0 & 600.0 & 36.5 & $2,865.0$ & 16.5 \\
23 & 107.7 & 101.3 & 28.0 & $3,725.0$ & 24.8 \\
32 & 137.7 & 101.3 & 32.0 & $2,041.0$ & 39.9 \\
34 & 9.9 & 101.3 & 35.0 & $27,618.0$ & 47.8 \\
37 & 72.1 & $1,300.0$ & 114.0 & 97.0 & 70.6 \\
38 & 33.3 & $2,700.0$ & 64.7 & $22,014.0$ & 105.1 \\
40 & 33.3 & $2,700.0$ & 190.0 & $22,136.0$ & 105.0 \\
41 & 34.4 & $2,700.0$ & 190.0 & $21,739.0$ & 104.5 \\
42 & 7.9 & 101.3 & 99.8 & $1,593.0$ & 104.8 \\
51 & 26.5 & 101.3 & 77.8 & $27,626.0$ & 104.8 \\
53 & 33.1 & 101.3 & 64.4 & $22,090.0$ & 105.0 \\
55 & 33.3 & 101.3 & 64.2 & $22,011.0$ & 105.1 \\
60 & 7.7 & 8.2 & 42.0 & 51.9 & 66.0 \\
61 & 7.7 & 250.0 & 42.0 & 51.9 & 66.4 \\
63 & 72.1 & 250.0 & 113.9 & 96.7 & 69.8 \\
64 & 80.2 & $6,000.0$ & 124.4 & 108.5 & 80.5 \\
65 & 80.2 & $6,000.0$ & 450.0 & $1,353.0$ & 62.1 \\
66 & 7.7 & 8.2 & 42.0 & 165.6 & 67.7 \\
68 & 8.1 & $1,300.0$ & 261.7 & 973.6 & 67.7 \\
70 & 64.4 & 250.0 & 127.4 & 662.0 & 67.7 \\
75 & 7.6 & 101.3 & 99.8 & $1,577.0$ & 130.5 \\
88 & 149.1 & 600.0 & 97.0 & $2,658.0$ & 18.3 \\
\hline & & & & &
\end{tabular}

The definition of global exergy efficiency $\left(\eta_{B}\right)$ for a distillery is presented in Eq. (7): the ratio between the exergy of products (alcohol, $\dot{B}_{\text {ETHANOL, and surplus }}$ electricity, $\left.P_{\mathrm{EL}}\right)$ and the difference of sugarcane exergy (input process) and the waste exergy (part of exergy that is not used in the process). Fig. 4 summarizes the results of the exergy analysis for scenario II.

$\eta_{B}=\frac{\dot{B}_{E T H A N O L}+P_{E L}}{\dot{B}_{S U G A R C A N E}-\dot{B}_{W A S T E}}$

The global exergy efficiency can be compared among the scenarios I, II and III. Fig. 5 presents this result as a function of the amount of hydrolysed bagasse. It can be concluded that, from a perspective of the rational use of the exergy, scenario III is better than scenarios II and I.

\subsection{Production Cost Analysis - Base Case}

Ethanol and electricity production cost can be assessed by doing the cost balance for each control volume. In case of a control volume with more than one product, e.g. steam turbine, the equality cost partition criteria was adopted. Table $6 \mathrm{a}$ and $6 \mathrm{~b}$ show the global cost balance for scenario II. It can be inferred that the primary source of cost is the sugarcane as feedstock followed by the distillery amortization.

Another interesting analysis that can be performed at this point is a production costs comparison between first and second generation sugarcane juice. The production cost 
of the latter reaches extremely high values for small values of the percentage of hydrolysed sugarcane bagasse. This comes from the fact that all the fixed cost of the hydrolysis plant is discharged in a small amount of produced juice
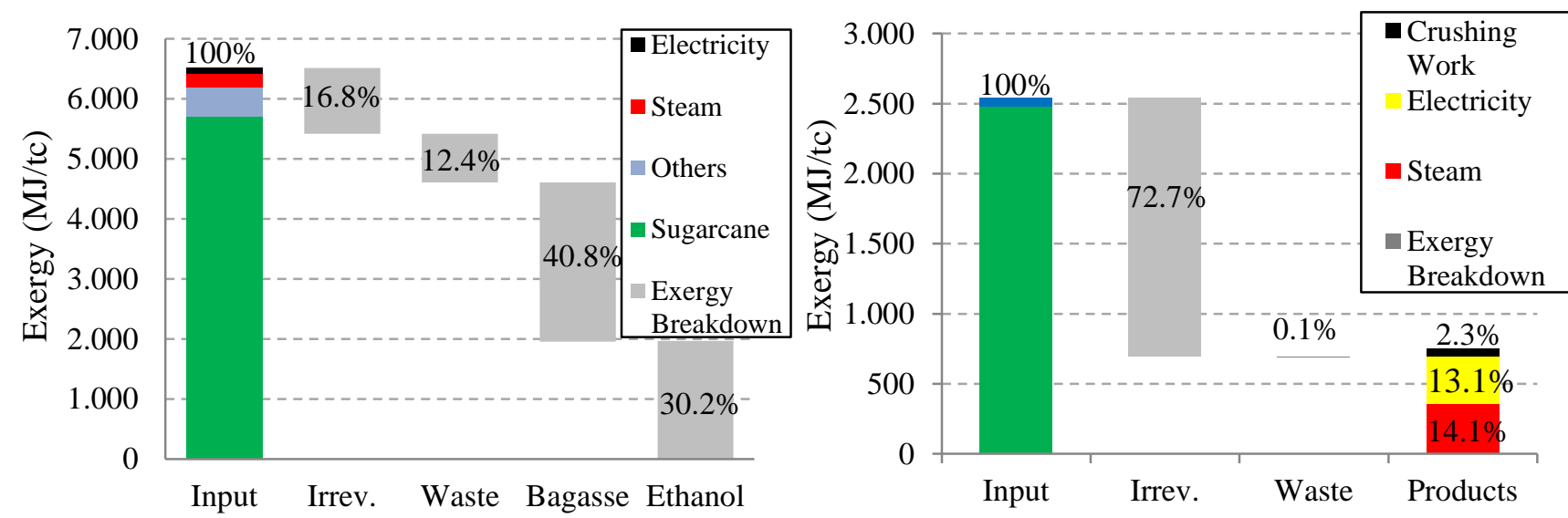

(a) - Distillery

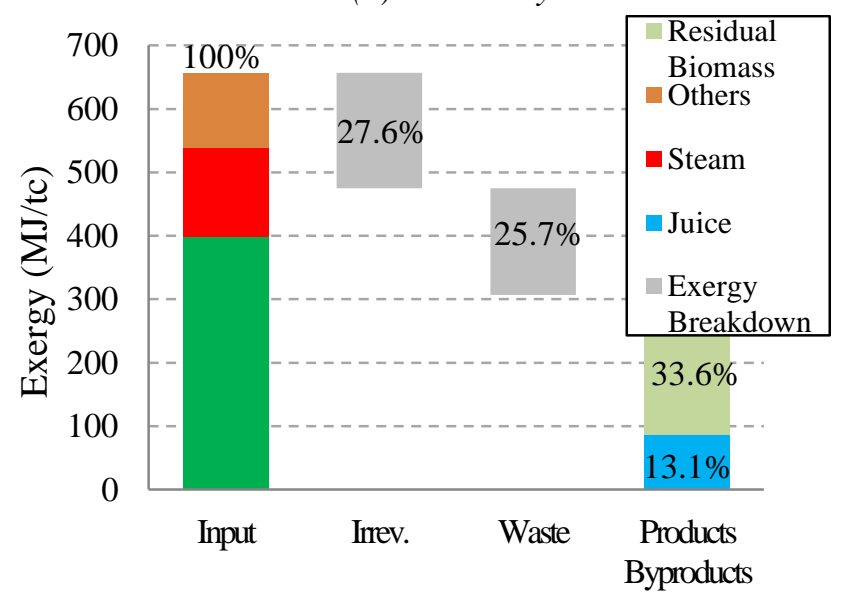

(c) - Hydrolysis Plant

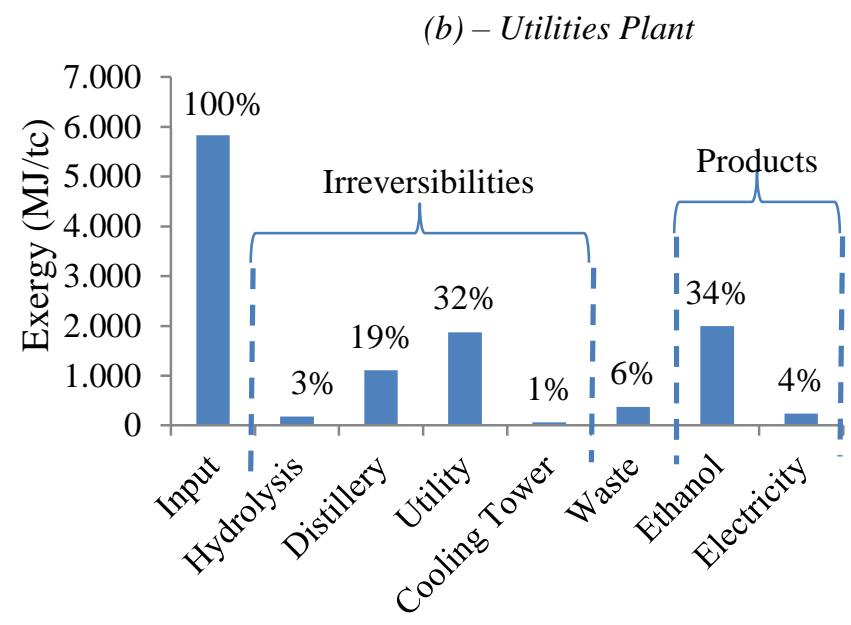

(d) - Global Plant

Figure 4. Exergy analysis for scenario II (15\% of hydrolysis).

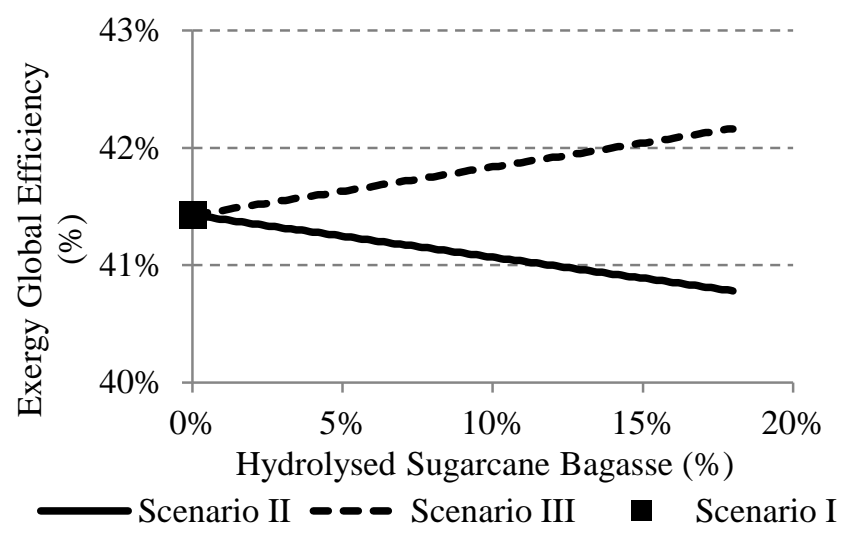

Figure 5. Global exergy efficiency for scenarios I, II and III.

Table 6a. Input Costs for Scenario II - Base Case.

\begin{tabular}{|c|c|c|c|c|c|c|}
\hline Input & $\begin{array}{l}\text { Monetary Exergy Cost } \\
\qquad\left(10^{-6} \mathrm{R} \$ / \mathrm{kJ}\right)\end{array}$ & $\begin{array}{c}\text { Specific } \\
\text { Exergy } \\
(\mathrm{kJ} / \mathrm{kg})\end{array}$ & $\begin{array}{l}\text { Specific Cost } \\
(\mathrm{R} \$ / \mathrm{kg})\end{array}$ & Cost Rate $(\mathrm{R} \$ / \mathrm{s})$ & $\begin{array}{l}\text { Specific Cost } \\
\text { (R\$/tc) }\end{array}$ & Flow \\
\hline Sugarcane $^{1}$ & 13.0 & 5695 & 0.074 & 10.29 & 74.09 & $\mathrm{~m}_{1}$ \\
\hline $\mathrm{H}_{2} \mathrm{SO}_{4}{ }^{1}$ & 360.1 & 1666 & 0.60 & 0.07 & 0.51 & $\mathrm{~m}_{54}$ \\
\hline $\mathrm{NaOH}^{1}$ & 738.5 & 2113 & 1.56 & 0.13 & 0.91 & $\mathrm{~m}_{43}$ \\
\hline $\mathrm{CaO}^{1}$ & 142.5 & 1965 & 0.28 & 0.04 & 0.31 & $\mathrm{~m}_{10}$ \\
\hline Replacement Water $^{1}$ & 5.20 & 50 & 0.00 & 0.04 & 0.29 & $\mathrm{~m}_{84}$ and $\mathrm{m}_{62}$ \\
\hline Distillery & - & - & - & 3.00 & 21.59 & Amortization \\
\hline Utilities Plant & - & - & - & 1.08 & 7.81 & Amortization \\
\hline Total Input & - & - & - & $\underline{\underline{15.5}}$ & $\underline{111.3}$ & \\
\hline
\end{tabular}

$1-[14]$ 
Table 6b. Output Costs for Scenario II - Base Case.

\begin{tabular}{l|ccccc}
\hline \multirow{2}{*}{ Output } & $\begin{array}{c}\text { Monetary Exergy Cost } \\
\left(10^{-6} \mathrm{R} \$ / \mathrm{kJ}\right)\end{array}$ & $\begin{array}{c}\text { Specific } \\
\text { Exergy } \\
(\mathrm{kJ} / \mathrm{kg})\end{array}$ & $\begin{array}{c}\text { Specific Cost } \\
(\mathrm{R} \$ / \mathrm{kg})\end{array}$ & $\begin{array}{c}\text { Cost Rate } \\
(\mathrm{R} \$ / \mathrm{s})\end{array}$ & $\begin{array}{c}\text { Specific Cost } \\
(\mathrm{R} \$ / \mathrm{tc})\end{array}$ \\
\hline Ethanol & 47.8 & 27618 & 1.32 & 13.06 & 93.99 \\
Electricity & $73.4^{\mathrm{a}}$ & - & - & 2.39 & 17.21 \\
\hline Total Output & - & - & - & 15.5 & $\mathrm{~m}_{36}$ \\
\hline $\mathrm{el}$ & & &
\end{tabular}

Total Output

$\underline{\underline{15.5}}$

$\underline{\underline{111.2}}$

a - 264.30 R $\$ / M W h$

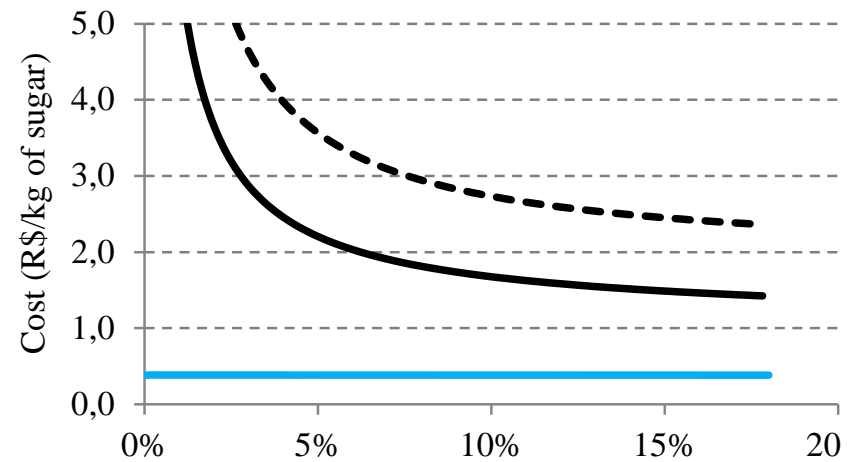

Hydrolysed Sugarcane Bagasse(\%)

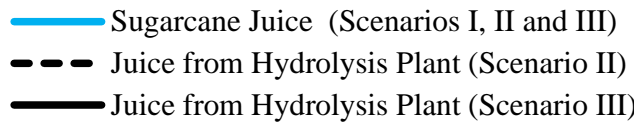

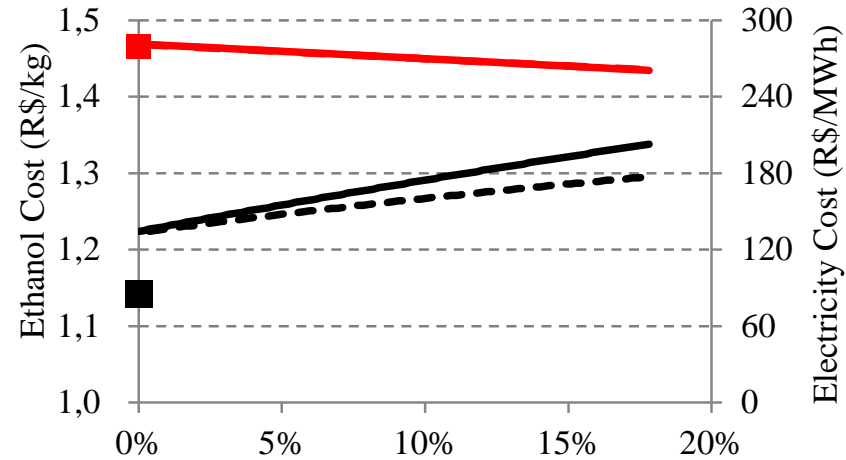

Hydrolysed Sugarcane Bagasse (\%)

- Electricity (Scenario I) — - - Ethanol (Scenario III)

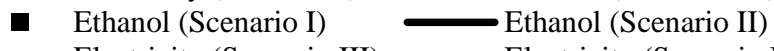

- Electricity (Scenario III) Electricity (Scenario II)

Figure 6. Juice (a), electricity and ethanol (b) production costs.

(Note: Electricity costs for scenarios II and III are overlapped in the chart)

For scenarios II and III, as shown in Fig. 6, production cost of the juice tends to stabilize when a large amount of bagasse is hydrolysed. Although the cost tends to decrease with the amount hydrolysed, it is still much more costly than the first generation juice. Scenario III shows a $40 \%$ cost reduction in relation to scenario II. This is a consequence of the higher hydrolysis yield and the use of the pentose for obtaining ethanol.

\subsubsection{Sensitivity Analysis - Base Case}

In order to compare the impact of changes in the main parameters, a dimensionless sensitivity coefficient is defined as in Eq. (8):

$\beta=\frac{\frac{\Delta \text { Product }}{\text { Product }}}{\frac{\Delta \text { Input }}{\text { Input }}}$

where:

- Product is a result obtained by the model. Four products were analyzed: (i) sugarcane juice cost, (ii) hydrolysed juice cost, (iii) ethanol cost, and (iv) electricity cost.

- Input is a specific process variable. Seven inputs were considered: (i) sugarcane price, (ii) investment, (iii) boiler LHV efficiency, (iv) cellulose conversion efficiency, (v) steam turbine isentropic efficiency, (vi) distillation steam consumption, and (vii) sucrose fermentation efficiency.

An array can be obtained by calculating $\beta$ for all possible combinations of Product-Input. Table 7 shows the dimensionless sensitivity array. As can be seen, sugarcane plays a key role in determining the cost of all products. In addition, the control volumes that present the highest irreversibility rate, i.e. boiler, steam turbine, fermentation and hydrolysis reactor, also present the highest dimensionless sensitivity coefficient.

Table 7. Dimensionless Sensitivity Array for Scenario II Base Case.

\begin{tabular}{l|cccc}
\hline \multicolumn{1}{c|}{ Product } & $\begin{array}{c}\text { Sugarcane } \\
\text { Juice Cost }\end{array}$ & $\begin{array}{c}\text { Hydrolysed } \\
\text { Juice Cost }\end{array}$ & $\begin{array}{c}\text { Ethanol } \\
\text { Cost }\end{array}$ & $\begin{array}{c}\text { Electricity } \\
\text { Cost }\end{array}$ \\
\hline Sugarcane Price & $\underline{\mathbf{0 . 8 4}}$ & $\underline{\mathbf{0 . 4 7}}$ & $\underline{\mathbf{0 . 6 4}}$ & $\underline{\mathbf{0 . 7 4}}$ \\
$\begin{array}{l}\text { Investment } \\
\text { Boiler LHV Efficiency }\end{array}$ & -0.15 & $\underline{\mathbf{0 . 5 6}}$ & 0.36 & 0.25 \\
$\begin{array}{l}\text { Cellulose Conversion } \\
\text { Efficiency }\end{array}$ & -0.01 & $\underline{\mathbf{- 0 . 5 6}}$ & -0.02 & 0.00 \\
$\begin{array}{l}\text { Steam Turbine Isentropic } \\
\text { Efficiency }\end{array}$ & -0.04 & -0.23 & -0.16 & $\underline{\mathbf{- 0 . 4 7}}$ \\
$\begin{array}{l}\text { Distillation Steam } \\
\text { Consumption }\end{array}$ & 0.00 & -0.03 & 0.04 & -0.04 \\
$\begin{array}{l}\text { Sucrose Fermentation } \\
\text { Efficiency }\end{array}$ & -0.04 & -0.24 & $\underline{\mathbf{- 0 . 9 6}}$ & -0.07 \\
\hline \multicolumn{4}{l}{ Note: The most significant coefficients are highlighted } \\
\end{tabular}

Note: The most significant coefficients are highlighted

\subsection{Economic Viability Assessment}

The economic viability assessment is based on the cash flow generated by the construction and operation of the plants for scenarios I, II and III as described in Table 4. During the first two years, cash flow is negative because of the investment expenses. From the third year until the end of operation, cash flow is generated by the sale of electricity and ethanol. The Internal Rate of Return (IRR) is then calculated to decide which scenario is the best one in terms of return on investment. Fig. 7 illustrates that although the IRR increases with the hydrolysis for scenario III, the best choice is still scenario I with IRR of $13.4 \%$ in real terms. Table 8 shows the main parameters used in the economic viability assessment. 
Table 8. Parameters Used in the Economic Analysis.

\begin{tabular}{ll}
\hline Parameters & Value \\
\hline Ethanol Price $^{1}$ & $1.31(\mathrm{R} \$ / \mathrm{l})$ \\
Tax on Revenue $^{2}$ & $8.30 \%$ \\
Electricity Price $^{3}$ & $102.10(\mathrm{R} \$ / \mathrm{MWh})$ \\
Income Tax & $34 \%$ \\
Depreciation (linear) & 10 years \\
Start-up time & 2 years \\
Salvage Value & 0 \\
Project lifetime & 20 years \\
\hline 1- [14] & \\
2- [15] & \\
3- Public Auction 02/2011-ANEEL (Net of taxes) [16]
\end{tabular}

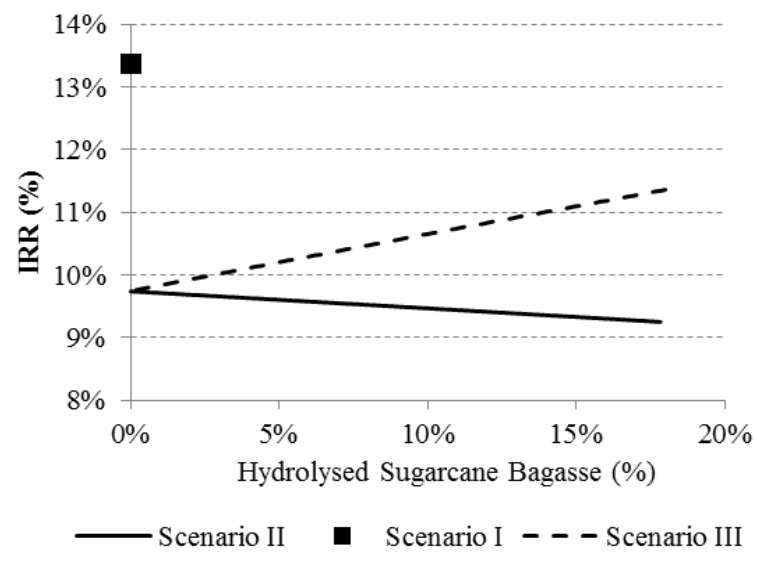

Figure 7. IRR for scenarios I, II and III.

\subsubsection{Sensitivity Analysis}

In order to evaluate the impact of changes in prices and investment expenses on the internal rate of return (IRR), taking into account eventual uncertainties on the investment of the hydrolysis plant and market fluctuations, a sensitivity analysis was carried out. For electricity price, sugarcane price and investment expenses, a variation of $\pm 25 \%$ over the original value (displayed in Tables $4,5 \mathrm{a}$ and 6 ) was assumed. For ethanol price, a variation of $\pm 20 \%$ was considered. Results are shown in Fig. 8. It can be verified that among the variables, the one that presents the most significant impact on the IRR, is the ethanol price: a variation of $\pm 20 \%$ causes the largest changes on the IRR in all the scenarios evaluated. Changes of $\pm 25 \%$ on sugarcane prices also affect the IRR significantly, but with less intensity than ethanol prices. Changes on investment of hydrolysis plant and electricity price have small impact on the IRR. An important conclusion at this point is that scenario I presents the highest IRR value among the three scenarios in the $\pm 25 \%$ interval.

\subsection{Comparison with Other Studies}

Tables 9 to 11 show several comparison parameters between results obtained in this model and previous publications.

As expected, the exergy efficiency varies significantly as a function of the hydrolysed biomass. Table 9 shows that lignocellulosic materials such as banana peduncle and sugarcane bagasse present exergy efficiency ranging from $13.1 \%$ to $28.7 \%$ depending on the analysed scenario.

In terms of global exergy efficiency (Table 10), scenario II actually is worse than scenario I. When compared with previous publications, global exergy efficiency is close to a first generation plant. This is due to the fact that most input exergy from sugarcane in the model is still processed in a traditional first generation distillery and only the surplus bagasse is hydrolysed.

Table 11 compares main efficiency parameters of the model with a 50/50 ethanol/sugar first generation plant [6] with different utilities plant configurations. As a result, global exergy efficiency in the model is lower than value obtained for an extraction-condensing system. This is mainly due to the choice 100/0 ethanol/sugar in the model, which is more irreversible. For the other parameters, it can be concluded that the results are consistent with this study
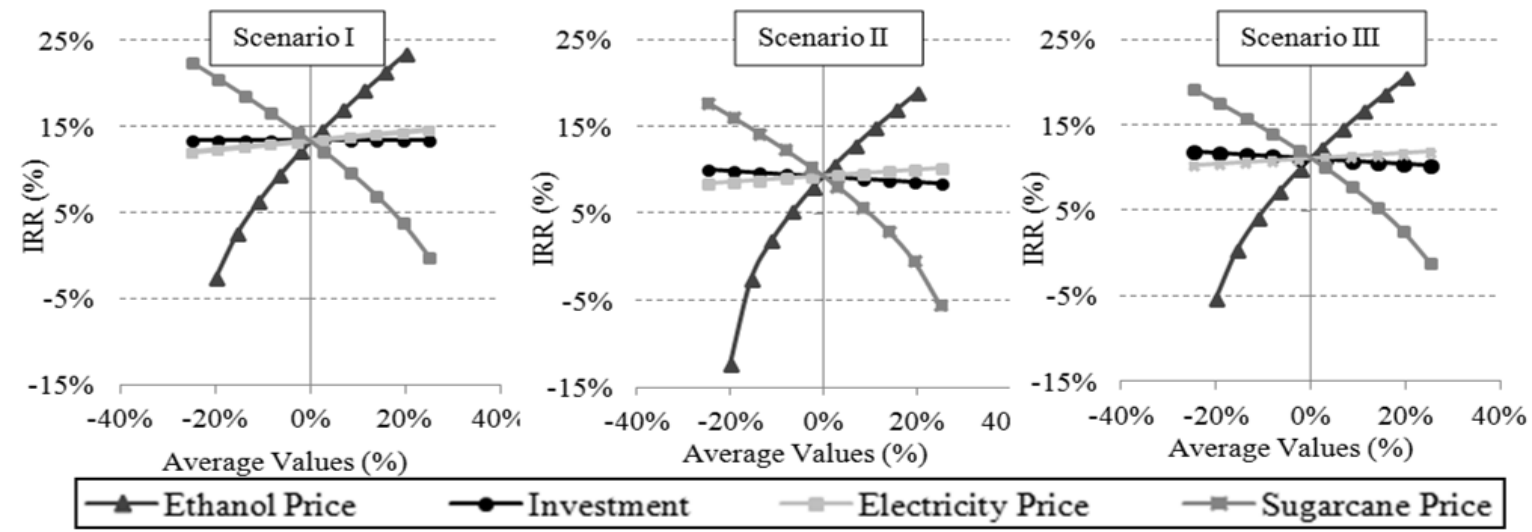

-Ethanol Price $\rightarrow$-Investment $\quad-$ Electricity Price

$\because-$ Sugarcane Price

Figure 8. Sensitivity analysis.

Table 9. Exergy Efficiency Comparison (Hydrolysis Only).

\begin{tabular}{|c|c|c|c|c|c|}
\hline & \multicolumn{2}{|c|}{ Acid Hydrolysis $^{1}$} & \multirow{2}{*}{ Enzymatic Hydrolysis $^{1}$} & \multicolumn{2}{|c|}{ Acid Hydrolysis $^{2}$} \\
\hline Origin & Banana Skin & Banana Pulp & & $\begin{array}{c}\text { Bagasse } \\
\text { (Scenario II) }\end{array}$ & $\begin{array}{c}\text { Bagasse } \\
\text { (Scenario III) }\end{array}$ \\
\hline Biomass & Starch & Starch & Lignocellulose & Lignocellulose & Lignocellulose \\
\hline
\end{tabular}

$1-[8]$;

2 - Results from the model 
Table 10. Global Exergy Efficiency Comparison.

\begin{tabular}{l|c}
\hline Biomass & Products \\
\hline Palm Tree $^{1}$ & Biodiesel \\
Sugarcane $^{3}$ & Sugar and Ethanol \\
Banana Skin (Starch) $^{1}$ & Ethanol \\
Banana Pulp (Starch) $^{1}$ & Ethanol \\
Banana Peduncle (Lignocellulose) $^{1}$ & Ethanol \\
\hline Sugarcane (Scenario I) $^{2}$ & Electricity and Ethanol \\
Sugarcane (Scenario II - 15\% of hydrolysis) $^{2}$ & Electricity and Ethanol \\
Sugarcane (Scenario III - 15\% of hydrolysis) $^{2}$ & Electricity and Ethanol \\
\hline
\end{tabular}

$1-[8]$

2 - Results from the model

$3-[6]$

Table 11. Key Results Comparison.

\begin{tabular}{|c|c|c|c|c|c|c|}
\hline Parameter & $\begin{array}{l}\text { Backpressure } \\
\text { System }^{1}\end{array}$ & $\begin{array}{c}\text { Extraction- } \\
\text { Condensing } \\
\text { System }^{1}\end{array}$ & $\begin{array}{l}\text { Supercritical } \\
\text { System }^{1}\end{array}$ & Scenario $\mathrm{I}^{2}$ & Scenario II $^{2}$ & Scenario $\mathrm{III}^{2}$ \\
\hline Ethanol Exergy Cost $(\mathrm{kJ} / \mathrm{kJ})$ & 3.08 & 2.91 & 2.54 & 2.23 & 2.42 & 2.36 \\
\hline Electricity Exergy Cost $(\mathrm{kJ} / \mathrm{kJ})$ & 5.01 & 5.16 & 3.66 & 4.58 & 4.23 & 4.22 \\
\hline Steam Exergy Cost $(\mathrm{kJ} / \mathrm{kJ})^{3}$ & 4.77 & 4.78 & 3.78 & 4.35 & 4.02 & 4.01 \\
\hline Steam Consumption $(\mathrm{kg} / \mathrm{tc})$ & 490 & 392 & 278 & 322.2 & 526.0 & 526.0 \\
\hline Sugar Exergy Cost $(\mathrm{kJ} / \mathrm{kJ})^{3}$ & 1.62 & 1.56 & 1.39 & - & - & - \\
\hline Exergy Efficiency (\%) & 45.8 & 44.7 & 50.0 & 41.4 & 40.9 & 42.0 \\
\hline Surplus Electricity $(\mathrm{kWh} / \mathrm{tc})$ & 48.5 & 64.9 & 142.3 & 90.5 & 65.4 & 62.3 \\
\hline Surplus Sugarcane Bagasse (\%) & 12.8 & 3.0 & 3.0 & 0.0 & 0.0 & 0.0 \\
\hline
\end{tabular}

1 - Different configurations for a 50/50 sugar/ethanol plant [6]

2 - Results from the model

3 - Differently from the monetary exergy cost $(\mathrm{R} \$ / \mathrm{kJ})$, the exergy cost $(\mathrm{kJ} / \mathrm{kJ})$ measures the amount of input Exergy necessary to produce one $\mathrm{kJ}$ of product Exergy, in this case electricity and ethanol.

\section{Conclusions}

The simulation shows that for scenarios II and III, steam consumption in the hydrolysis plant limits to $18 \%$ the amount of bagasse that can be hydrolysed. This is a direct consequence of the steam requirement in the distillation and heating process inside the hydrolysis plant, which is approximately the same for scenarios II and III. Because of most fermentable sugar is from the first generation plant, steam consumption in the distillery plant is slightly affected by hydrolysis yield or pentose fermentation. In terms of productivity improvement, hydrolysis can increase the net ethanol production by $3.7 \%$ and $8.1 \%$, for scenarios II and III respectively, which leads, respectively, to 136 and 286 liters of ethanol per dry ton of sugarcane.

Regarding the exergy analysis, hydrolysis under scenario II causes a small drop in global exergy efficiency, from $41.4 \%$ (scenario I) to $40.9 \%$ (scenario II). The situation is reversed for scenario III in which the global exergy efficiency increases from $41.4 \%$ to $42.0 \%$. This is a direct consequence of higher saccharification yield and pentose fermentation. Exergy analysis still shows that, for all three scenarios, the main source of irreversibility is the utilities plant, notably the boiler. This is an expected result because the combustion reaction is highly irreversible.

The economic viability assessment based on the IRR shows that scenario I, which is a first generation plant, is the best choice with IRR of $13.4 \%$, followed by scenarios III and II with IRR of $11.1 \%$ and $9.3 \%$ respectively. Sensitivity analysis shows that the scenario I is still the best choice even if main parameters change $\pm 25 \%$.

\section{Acknowledgements:}

The corresponding author acknowledges $\mathrm{CNPq}$ (Brazilian National Council of Scientific and Technological Development) for grant 306033/2012-7.

\section{Nomenclature}

b

Specific exergy $(\mathrm{kJ} / \mathrm{kg})$
$\dot{\mathrm{B}}_{\text {ETHANOL }} \quad$ Ethanol exergy flow rate $(\mathrm{kW})$

$\dot{B}_{\text {SUGARCANE }}$ Sugarcane exergy flow rate $(\mathrm{kW})$

$\dot{B}_{\text {WASTE }} \quad$ Waste exergy flow rate $(\mathrm{kW})$

c Specific monetary exergy cost

$(\mathrm{R} \$ / \mathrm{kJ})$

Acquisition cost of the equipment

C (R\$)

$f_{a} \quad$ Capital recovery factor

Operational and maintenance fixed

omf cost factor

$f_{\text {omv }} \quad$ Operational and maintenance variable

cost factor

FC Load factor

h $\quad$ Specific enthalpy $(\mathrm{kJ} / \mathrm{kg})$

I $\quad$ Irreversibility rate $(\mathrm{kW})$

IRR Internal rate of return (\%)

j Interest rate (\%)

$\dot{\mathrm{m}} \quad$ Mass flow rate $(\mathrm{kg} / \mathrm{s})$

$\mathrm{N} \quad$ Equipment lifetime (year)

$\mathrm{P} \quad$ Pressure $(\mathrm{kPa})$

$\mathrm{P}_{\mathrm{EL}} \quad$ Electrical power $(\mathrm{kW})$

$\dot{\mathrm{Q}} \quad$ Heat transfer rate $(\mathrm{kW})$

$\mathrm{T} \quad$ Temperature $\left(\mathrm{K},{ }^{\circ} \mathrm{C}\right)$

$\mathrm{T}_{0} \quad$ Ambient temperature $\left(\mathrm{K},{ }^{\circ} \mathrm{C}\right)$

$\mathrm{T}_{\text {oper }} \quad$ Expected yearly operation time (h)

$\dot{\mathrm{W}} \quad$ Shaft power $(\mathrm{kW})$

$\dot{\mathrm{Z}} \quad$ Equipment depreciation rate $(\mathrm{R} \$ / \mathrm{s})$

\section{Greek Symbols}

$\beta \quad$ Sensitivity Coefficient

$\Delta \quad$ Variation

$\eta_{B} \quad$ Exergy efficiency

$\begin{array}{ll}\text { Subscripts } & \\ \text { in } & \text { Inlet } \\ \text { out } & \text { Outlet } \\ \text { Q } & \text { heat } \\ \text { W } & \text { work }\end{array}$




\section{References}

[1] M. Sanchez, Latin America -- the 'Persian Gulf' of Biofuels?, The Washington Post. February 23, 2007. Accessed March 30, 2014. Available at: http://www.washingtonpost.com/wpdyn/content/article/2007/02/22/AR2007022201361.html.

[2] RFA - Renewable Fuels Association, Ethanol industry outlook, World Fuel Ethanol Production, 2012.

[3] J. Goldemberg, The Brazilian biofuels industry, Biotechnology for Biofuels, p.1-6, 2008.

[4] M.O.S. Dias, T.L. Junqueira, O. Cavallet, M.P. Cunha, C.D.F. Jesus, C.E.V. Rossel, R.M. Filho, A. Bonomi, Integrated versus stand-alone second generation ethanol production from sugarcane bagasse and trash, Bioresource Technology, 103. 152-161, 2011

[5] EES Engineering Equation Solver, 2012. Available at: www.fchart.com/ees/

[6] L. F. Pellegrini, Thermo-Economic-Environmental analysis applied to the combined production of sugar, ethanol and electricity (in Portuguese), 346p., Doctoral Thesis, Mechanical Engineering Department, Polytechnic School of the University of São Paulo, São Paulo, 2009.

[7] A. V. Ensinas, Thermal integration and termoeconomic optimization applied to the industrial process of sugar and ethanol from surgarcane (in Portuguese), $229 \mathrm{p}$., Doctoral Thesis, University of Campinas, Mechanical Engineering Department, Campinas, 2009.

[8] H. I. Velásquez, Exergetic and exergo-enviromental evaluation of the biofuel production (in Portuguese), 235p., Doctoral Thesis, Mechanical Engineering Department, Polytechnic School of the University of São Paulo, São Paulo, 2009.

[9] L. F. Pellegrini, S. Oliveira Junior, Combined production of sugar, ethanol and electricity: Thermoeconomic and environmental analysis and optimization, Energy 36, 3704-3715, 2011
[10] P. A. Soares, J. L. Olivério, The Dedini vision - Acid hydrolysis - A practical experience of the process Dedini Rapid Hydrolysis (DRH), Workshop on hydrolysis, Technological Centre of Bioethanol - CTBE, $1,1-53,2009$

[11] P. A. Soares, C. E. Rossell, Cellulose conversion using the Organosolv technology (Vol. 3) (in Portuguese). São Paulo: Naippe, 2009

[12] J. A. Fortman, Techno-economic comparison of hot water and dilute acid pretreatment for biochemical production of ethanol from corn stover and evaluation of alternative scenarios to purchasing cellulase enzymes, Graduate Theses and Dissertations. Paper 10495, Iowa State University Iowa State University, 2009

[13] M.J. Taherzadeh, K. Karimi, Acid-based hydrolysis processes for ethanol from lignocellulosic materials: A review, BioResources, 2, 472-499, 2007

[14] PACEGE-ESALQ, Production costs of sugarcane, ethanol and sugar in Brazil: Harvest 2011/2012, 1st Ed, February 2012

[15] M.R. Joia, M.S.F.A Fregonesi, A.J, Rezende, Tax analysis of the sugarcane industry in Brazil, Qualit@s Revista Eletrônica Vol.1. N¹, 2011

[16] ANEEL (2011). Brazilian Electricity Regulatory Agency. Accessed March 30, 2014. Available: http://www.mme.gov.br/mme/galerias/arquivos/acoes/E nergia/Leilxes_de_Transmissxo_-_resultados_20112012_xfinalx_x3x.pdf 